\title{
Game theory and contemporary conflicts
}

Fight is a normal task of humanity — battle no.

Cyprian Kamil Norwid (Polish poet, dramatist, painter, and sculptor)

\section{Introduction}

Fight is a universal phenomenon. This premise has been the primary thesis of the article. The aim of this paper is to demonstrate that various fights, in the sense of conflicts, can be described using the terms of game theory. It is possible in the case of both civil and military problems. The article contains examples of various uses of the application of game theory to find solutions to real problems.

Game theory is a relatively new part of mathematics. First studies in this field were published in the early 1920s. Among them are works of Emil Borel (1921) and John von Neumann (1928). It should not be forgotten that Hugo Steinhaus a famous Polish mathematician - was the first to use the term "game theory". 1 However, the post-war years (after 1945) were a good time for the intensive development of game theory. The major works were created in the 1950s. At this time, John Forbes Nash formulated the equilibrium theorem. ${ }^{2}$ Nash worked for the RAND Corporation for a long time, where his work on game theory made

${ }^{1}$ H.D. Steinhaus, Definicje potrzebne do teorii gier i pościgu, Lwów 1927.

2 J. Cave, Introduction to Game Theory, Santa Monica 1987, https://www.rand.org/pubs/papers/P7336.html (accessed: 8.01.2018). 
him a leading expert on the Cold War conflict, which dominated RAND's work. RAND Corporation is a research organization that develops methodology in the field of system analysis, system modelling and computer simulations. ${ }^{3}$

\section{Universalism of game theory}

In terms of game theory, a game is given by a set of rules and a set of players, each with their own set of strategies. The main problem of game theory comes down to the following question described by von Neumann ${ }^{4}$ :

If $n$ players $\mathrm{P}_{1}, \mathrm{P}_{2}, \mathrm{P}_{3}, \ldots, \mathrm{P}$ take part in the game of strategy $\Gamma$, then the question is how must one of the participants $\mathrm{P}_{m}$ play in order to achieve a most advantageous result?

Games are an integral part of the functioning of societies. As a result of increasing complexity of the means of production and social relations the artificial games methodology was created (as opposed to common party or social games). The aim of such artificial games is to analyze human social activity. Artificial games are considered to be management games, as they are identified with decision-making processes and cooperation processes between different players. The value of information will depend on the extent to which it may influence the decisions made by the entity, and thus the change of reality. ${ }^{5}$

A special variant of management game is a war game. A war game is a multivariate model of functioning of the specific military action system. War games reflect the decision-making process taking place during combat operations, as well as the process of cooperation of decision-makers in order to achieve a goal of the system. Methods of mathematical modelling in relation to strategic, operational and tactical activities are commonly used in modern armies. The advantages of mathematical models applied to solve complex decision-making problems are evident and widely accepted. They improve the efficiency of management and command of complex military systems.

3 T. Robinson, Game Theory and Politics: Recent Soviet Views, Santa Monica 1970, www. rand.org/pubs/research_memoranda/RM5839.html (accessed: 1.12.2017). See also: T. Hamilton, R. Mesic, Using Game Theory to Analyze Operations Against Time-Critical Targets, Santa Monica 2004, https://www.rand.org/pubs/research_briefs/RB108.html (accessed: 6.01.2018); W.L. Perry, J. Moffat, Information Sharing Among Military Headquarters: The Effects on Decisionmaking, Santa Monica 2004; W.L. Perry, B. Pirnie, J. Gordon, The Future of Warfare: Issues from the 1999 Army After Next Study Cycle, Santa Monica 2001.

4 J. von Neumann, O. Morgenstern, Theory of Games and Economic Behavior, New Jersey 1944. See also: G. Owen, Teoria gier, transl. A. Wieczorek, Warszawa 1975; S.I. Gass, Programowanie liniowe, transl. J. Michalczyk, Warszawa 1980; K. Ficoń, Badania operacyjne stosowane. Modele i aplikacje, Warszawa 2006.

5 T. Dukiewicz, "Information operations", [in:] Security Forum 2016: Volume of Scientific Papers, ed. J. Ušiak, Banska Bystrica 2016, p. 49. 
Implementation of mathematical modelling in command of the units has a significant influence on increasing efficiency and effectiveness of the entire command process during military operations. The development of simulation fighting models created an utterly new category of management game - war games. Many fields of science, such as war doctrine, social and political sciences are incorporated in such games. ${ }^{6}$

A system thinking approach and rich historical experience of many ancient armies in preparation and conduct of combat operations are the basis of war games. Models within game theory are abstract representations of real-life situations. The main problem of game theory comes down to finding an optimal solution to the task of linear programming. ${ }^{7}$ In fact, many actual or potential conflicts of interest can be resolved in the form of linear programming, as will be shown in the following examples.

\section{Marketing strategies: A non-military example}

The first example concerns the cooperation between transport companies operating in Poland. Companies operating on the Polish market have adopted various marketing strategies. ${ }^{8}$ A full comparative analysis of all the possible actions of all the participants of the simulation game offers the solution. The type of adopted strategy depends on a number of economic factors and relationships between competitors. The set of strategies consists of the following categories: defence strategies, active strategies and passive strategies. ${ }^{9}$

Such situations could be seen as a problem of game theory. Let us consider the following situation:

- there are five competing companies;

- all companies are small (their market position is relatively weak);

- all companies are interrelated.

Table 1 shows the degree of consolidating the actions taken by each individual company. Number 1 denotes full cooperation between companies and the symbol 0 denotes utter lack of cooperation.

${ }^{6}$ I. Pikner, V. Galatík, "The use of the armed forces in the postmodern wars", [in:] The 21st International Scientific Conference "Knowledge-Based Organization": Management and Military Sciences, Sibiu 2015, pp. 90-93.

7 D.E. Johnson et al., Joint Paths to the Future Force: A Report on Unified Quest 2004, Santa Monica 2006, https://www.rand.org/pubs/monographs/MG391.html (accessed: 8.12.2018).

${ }^{8}$ M. Malawski, A. Wieczorek, Konkurencja i kooperacja. Teoria gier w ekonomii i naukach spolecznych, Warszawa 2004. See also: J.C. Harsanyi, R. Selen, A General Theory of Equilibrium Selection in Games, Cambridge-London 1988; E. Konarzewska-Gubala, Programowanie przy wielorakości celów, Warszawa 1980; M. Wolny, “Quasi-klasyczna analiza decyzji złożonych”, [in:] Metody i techniki analizy informacji, eds. Z. Bubnicki, O. Hryniewicz, R. Kulikowski, Warszawa 2002.

9 W. Wrzosek, Strategie marketingowe, Warszawa 2004, p. 63. 
Table 1. Connections between companies

\begin{tabular}{|c|c|c|c|c|c|}
\hline & A & B & C & D & E \\
\hline A & - & 1 & 0 & 1 & 0 \\
\hline B & 1 & - & 0 & 1 & 0 \\
\hline C & 1 & 1 & - & 1 & 1 \\
\hline D & 1 & 1 & 0 & - & 1 \\
\hline E & 0 & 0 & 0 & 1 & - \\
\hline
\end{tabular}

Directions and relative strengths of relations between companies can be inferred based on information presented in Table 1. The situation can be then illustrated by a graph, such as the one in Figure 1.

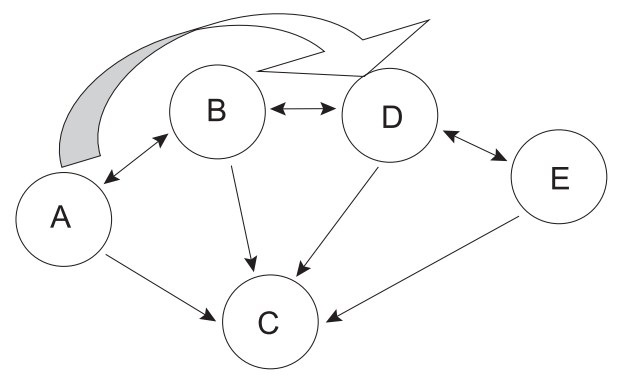

Figure 1. Graph of interactions between transport companies Source: own study.

The real situation on the Polish transport market may be represented by the matrix-form game, in a following way:

- a set of players is created;

— along with a set of possible pure strategies for each player;

- lack of negative outcomes among decision variants is assumed;

- the aim for all players is to choose an optimal strategy;

- in the event of all players choosing the same strategy, the outcome would be simply payoffs to all players;

- model of the optimization problem is then created;

- optimal solution would be a set of pure strategies. ${ }^{10}$

Company $\mathrm{C}$ in the presented example is obliged to choose a defensive strategy. The reason for this is that all of the other companies have concluded an agreement between them as shown in Figure 1. The competitive environment poses a threat to company $\mathrm{C}$ due to aggregated activities of other companies. Companies which have cooperation agreements (A, B, D, E - Figure 1) would be able

${ }^{10}$ H. Spustek, "Analiza wielokryterialna strategii marketingowych w transporcie”, Logistyka 2014, no. 3 . 
to work actively in the area where company C's activity is limited. As a consequence, in addition to the defensive strategy company $\mathrm{C}$ is also forced to take steps typical of active strategies. ${ }^{11}$

\section{Tactical game: A military example}

Suppose that the "red" team assignment is to assume control of the object defended by the "blue" team. Commander of the "red" unit is analyzing possible ways to defend the object (courses of the "blue" team action). ${ }^{12}$

The matrix of the tactical game is made up of nine elements, each marked by one of three possible outcomes: "defeat", "victory" and "tie", as shown in Table 2. Let three possible courses of the "red" team action be: $r_{1}, r_{2}, r_{3}$ and similarly for the "blue" team: $b_{1}, b_{2}, b_{3}$. Outcome of +1 would be assigned to "victory", while 0 would be the outcome of "tie", and -1 would be the outcome of a "defeat". The game matrix using such a metric is shown in Table 3.

Table 2. Matrix of the game for the tactical problem — step 1

\begin{tabular}{|c|c|c|c|c|}
\hline \multicolumn{2}{|c|}{} & \multicolumn{3}{c|}{ Actions of the "blue" team } \\
\cline { 2 - 5 } \multicolumn{2}{|c|}{} & $\mathrm{b}_{1}$ & $\mathrm{~b}_{2}$ & $\mathrm{~b}_{3}$ \\
\hline \multirow{3}{*}{ Actions of the "red" team } & $\mathrm{r}_{1}$ & defeat & victory & victory \\
\cline { 2 - 5 } & $\mathrm{r}_{2}$ & tie & victory & tie \\
\cline { 2 - 5 } & $\mathrm{r}_{3}$ & victory & tie & defeat \\
\hline
\end{tabular}

Table 3. Matrix of the game for the tactical problem - step 2

\begin{tabular}{|c|c|c|c|c|}
\hline \multicolumn{2}{|c|}{} & \multicolumn{3}{|c|}{ Actions of the "blue" team } \\
\cline { 2 - 5 } \multicolumn{2}{|c|}{} & $\mathrm{b}_{1}$ & $\mathrm{~b}_{2}$ & $\mathrm{~b}_{3}$ \\
\hline \multirow{3}{*}{ Actions of the "red" team } & $\mathrm{r}_{1}$ & -1 & 1 & 1 \\
\cline { 2 - 5 } & $\mathrm{r}_{2}$ & 0 & 1 & 0 \\
\cline { 2 - 5 } & $\mathrm{r}_{3}$ & 1 & 0 & -1 \\
\hline
\end{tabular}

In the event that the commander of "red" troops will adopt the $\mathrm{r}_{1}$ strategy while the commander of the "blue" troops will adopt the $b_{1}$ strategy, the defended object will not be captured. On the contrary, the "red" team will successfully cap-

11 W. Wrzosek, op. cit., p. 64.

12 R.E. Darilek et al., Information Superiority and Game Theory: The Value of Information in Four Games, Santa Monica 1999, https://www.rand.org/pubs/reprints/RP806.html (accessed: 9.10.2018). 
ture the objective using the $r_{1}$ strategy if the commander of the "blue" troops would adopt the $b_{2}$ or $b_{3}$ strategy. The outcome of the game in all other cases could be predicted in a similar manner. The conflict situation is therefore based on the mutually contradictory goals of both teams. The "red" team is trying to maximize results of the game by choosing an appropriate strategy, while the "blue" team is trying to choose a strategy that leads to minimizing this result. The final results depend on the action of both sides.

So far it has been assumed that both players used a single strategy chosen from the given pure strategies set. Meanwhile, players can choose mixed strategies. Mixed strategies are an active randomization, with given probabilities, that determines the player's decision. ${ }^{13}$

\section{Role of information in the war game}

The structure of the game in both given examples was assumed to be common knowledge among the players. Information superiority and information dominance have a special role in the war game, as described in Table 4 . There is a clear difference between information superiority and information dominance. We may say that information dominance is a wider notion than information superiority. ${ }^{14}$ The details of four games are given in Table 5.

Table 4. Information superiority and information dominance

\begin{tabular}{|c|c|c|c|c|}
\hline & Side 1 & Side 2 & $\begin{array}{l}\text { Information } \\
\text { superiority }\end{array}$ & $\begin{array}{c}\text { Information } \\
\text { dominance }\end{array}$ \\
\hline Correct information & $\checkmark$ & $\checkmark$ & & \\
\hline Correct information & $\checkmark$ & & $\checkmark$ & \\
\hline $\begin{array}{l}\text { Correct information } \\
+ \\
\text { Side } 1 \text { knows Side } \\
2 \text { choice }\end{array}$ & $\begin{array}{l}\checkmark \\
\checkmark\end{array}$ & $\checkmark$ & $\checkmark$ & \\
\hline $\begin{array}{l}\text { Correct information } \\
+ \\
\text { Side } 1 \text { knows Side } 2 \\
\text { choice }\end{array}$ & $\begin{array}{l}\checkmark \\
\checkmark\end{array}$ & & & $\checkmark$ \\
\hline
\end{tabular}

13 T.L. Turocy, B. Stengel, "Game theory”, [in:] Encyclopedia of Information Systems, ed. H. Bidgoli, Amsterdam-Boston 2002, pp. 403-420.

14 R.E. Darilek et al., Measures of Effectiveness for the Information-Age Army, Santa Monica 2001, www.rand.org/publications/MR/MR1155/ (accessed: 1.12.2017), pp. 24-25. See also: R.E. Darilek et al., Issues and Insights from the Army Technology Seminar Game, Santa Monica 2001; R.E. Darilek et al., Information Superiority... 
Table 5. Four types of information games

\begin{tabular}{|c|l|}
\hline $\begin{array}{c}\text { Type of } \\
\text { game }\end{array}$ & \multicolumn{1}{c|}{ Description of the game } \\
\hline Game 1 & $\begin{array}{l}\text { Side 1 and Side 2 have common and correct knowledge of all the values of the } \\
\text { payoffmatrix. Bothsideshavethesameinformationaboutpayoffs butareigno- } \\
\text { rant about each other's choices. } \\
\text { Neither has superior knowledge. }\end{array}$ \\
\hline Game 2 & $\begin{array}{l}\text { Side } 1 \text { has correct knowledge of all the values of the payoff matrix while } \\
\text { Side } 2 \text { has a completely incorrect understanding of the payoff matrix. Side } \\
\text { 2 will make decisions based on erroneous information. } \\
\text { Side 1 has information superiority. }\end{array}$ \\
\hline Game 3 3 & $\begin{array}{l}\text { Both Side 1 and Side 2 have correct information about the payoff matrix, } \\
\text { as in Game 1, but Side 1 additionally knows Side 2's choice. Side 2 choos- } \\
\text { es his minimax strategy from the correct matrix. Side 1, however, knows } \\
\text { the choice Side 2 makes, and rather than choose his maximin strategy, he } \\
\text { focuses only on the payoffs corresponding to the minimax choice of Side 2 } \\
\text { and maximizes his payoff. This simulates the case in which Side 1 has } \\
\text { perfect intelligence and, as a result, another kind or higher level of } \\
\text { information superiority. }\end{array}$ \\
\hline Game 4 & $\begin{array}{l}\text { Side 1 has correct information, while Side 2 has incorrect information, and } \\
\text { Side 1 knows Side 2's choice. In this game Side 1 has correct knowledge } \\
\text { of the whole payoff matrix and Side 2 has a completely incorrect payoff } \\
\text { matrix composed of a second set of random numbers between } 0 \text { and 100, } \\
\text { as in Game 2. Side 2 chooses his minimax strategy from the incorrect } \\
\text { information. Side 1 knows the choice of Side 2. Thus, Side 1 enjoys not } \\
\text { only information superiority but also information dominance. }\end{array}$ \\
\hline
\end{tabular}

\section{Conclusion}

The article consists of two parts. The first describes possible applications of game theory in the market cooperation between transport companies. The second part contains two examples illustrating military problems.

Based on the conducted analysis, one can formulate the following conclusions:

— game theory can be effectively used to model and analyze military problems;

- military models are structured in a similar way to non-military models;

- the essential role of information was described in the military example;

- information dominance is a wider notion than information superiority. 


\section{Bibliography}

Cave J., Introduction to Game Theory, Santa Monica 1987, www.rand.org/pubs/papers/P7336.html (accessed: 1.12.2017).

Darilek R.E., Brown S., Bracken J., Information Superiority and Game Theory: The Value of Information in Four Games, Santa Monica 1999, https://www.rand.org/pubs/reprints/RP806.html (accessed: 9.10.2018).

Darilek R.E., Perry W., Bracken J., Gordon J., Nichiporuk B., Measures of Effectiveness for the Information-Age Army, Santa Monica 2001, www.rand.org/publications/MR/MR1155/ (accessed: 1.12.2017).

Darilek R.E., Pirnie B., Drezner S.M., Joe L., Gordon J., Perry W.L., Issues and Insights from the Army Technology Seminar Game, Santa Monica 2001.

Dukiewicz T., "Information operations", [in:] Security Forum 2016: Volume of Scientific Papers, ed. J. Ušiak, Banska Bystrica 2016.

Ficoń K., Badania operacyjne stosowane. Modele i aplikacje, Warszawa 2006.

Gass S.I., Programowanie liniowe, transl. J. Michalczyk, Warszawa 1980.

Hamilton T., Mesic R., A Simple Game-Theoretic Approach to Suppression of Enemy Defenses and Other Time Critical Target Analyses, Santa Monica 2004, www.rand.org/pubs/documented briefings/DB385.html (accessed: 1.12.2017).

Hamilton T., Mesic R., Using Game Theory to Analyze Operations Against Time-Critical Targets, Santa Monica 2004, https://www.rand.org/pubs/reprints/RP806.html (accessed: 19.02.2018).

Harsanyi J.C., Selen R., A General Theory of Equilibrium Selection in Games, Cambridge-London 1988.

Johnson David E., Wilson P.A., Darilek R.E., Rohn L.L., Joint Paths to the Future Force: A Report on Unified Quest 2004, Santa Monica 2006, https://www.rand.org/pubs/monographs/MG391. html (accessed: 8.12.2018).

Konarzewska-Gubala E., Programowanie przy wielorakości celów, Warszawa 1980.

Malawski M., Wieczorek A., Konkurencja i kooperacja. Teoria gier w ekonomii i naukach społecznych, Warszawa 2004.

Neumann J., Morgenstern O., Theory of Games and Economic Behavior, New Jersey 1944.

Owen G., Teoria gier, transl. A. Wieczorek, Warszawa 1975.

Perry W.L., Moffat J., Information Sharing Among Military Headquarters: The Effects on Decisionmaking, Santa Monica 2004.

Perry W.L., Pirnie B., Gordon J., The Future of Warfare: Issues from the 1999 Army After Next Study Cycle, Santa Monica 2001.

Pikner I., Galatík V., "The use of the armed forces in the postmodern wars", [in:] The 21st International Scientific Conference "Knowledge-Based Organization": Management and Military Sciences, Sibiu 2015.

Porche I., Paul Ch., York M., Serena Ch., Sollinger J., Axelband E., Min E., Held B., Redefining Information Warfare Boundaries for an Army in a Wireless World, Santa Monica 2013, www. rand.org/pubs/monographs/MG1113.html (accessed: 1.12.2017).

Przemieniecki J.S., Mathematical Methods in Defense Analyses, Reston 2000.

Robinson T., Game Theory and Politics: Recent Soviet Views, Santa Monica 1970, www.rand.org/ pubs/research_memoranda/RM5839.html (accessed: 1.12.2017).

Shubik M., Games for Society, Business and War, unpublished manuscript, 1970.

Shubik M., On Gaming and Game Theory, Santa Monica 1971, https://www.rand.org/pubs/reprints/ RP806.html (accessed: 22.01.2018).

Spustek H., "Analiza wielokryterialna strategii marketingowych w transporcie", Logistyka 2014, no. 3 .

Studia nad Autorytaryzmem i Totalitaryzmem 41, nr 1, 2019

(C) for this edition by CNS 
Steinhaus H.D., Definicje potrzebne do teorii gier i pościgu, Lwów 1927.

Turocy T.L., Stengel B., "Game theory”, [in:] Encyclopedia of Information Systems, ed. H. Bidgoli, Amsterdam-Boston 2002, pp. 403-420.

Wolny M., "Quasi-klasyczna analiza decyzji złożonych", [in:] Metody i techniki analizy informacji, eds. Z. Bubnicki, O. Hryniewicz, R. Kulikowski, Warszawa 2002.

Wrzosek W., Strategie marketingowe, Warszawa 2004.

\section{GAME THEORY AND CONTEMPORARY CONFLICTS}

\section{Summary}

The article presents the application of game theory in the context of civil and military security. Game theory is used to study conflict situations involving more than one decision-maker. Special emphasis was given to the significant role of information in modern military operations. The article contains examples illustrating similarities between civil and military problems.

Keywords: game theory, tactical game, information superiority.

Tomasz Dukiewicz

tdukiewicz@uni.opole.pl

Henryk Spustek

hspustek@uni.opole.pl 